\title{
Kapitał społeczny osób niewidomych w wieku produkcyjnym a ich sytuacja na rynku pracy
}

\section{Social capital of the blind in working age and their professional situation}

\begin{abstract}
Streszczenie:
Niniejszy artykuł powstał w oparciu o badania prowadzone w ramach niepublikowanej pracy magisterskiej o takim samym tytule obronionej w 2017 roku na Wydziale Etnologii i Nauk o Edukacji w Cieszynie, Uniwersytetu Śląskiego w Katowicach. Promotorem pracy był prof. dr hab. Zenon Gajdzica. Praca poświęcona jest kapitałowi społecznemu osób ze znaczną niepełnosprawnością wzroku oraz ich sytuacji zawodowej. W swoich badaniach za cel postawiłam sobie diagnozę kapitału społecznego osób niewidomych w wieku produkcyjnym oraz zbadanie zależności pomiędzy nim a sytuacją zawodową tychże osób. W swoich badaniach będę się posługiwała koncepcją indywidualnego kapitału społecznego, według której jest on zasobem jednostki. Zgodnie z opisaną w części teoretycznej literaturą przyjmuję, że kapitał społeczny może warunkować aktywność zawodową osób z niepełnosprawnością, w tym osób niewidomych. W niniejszej pracy za osoby niewidome uznawane są wszystkie osoby posiadające orzeczenie o znacznym stopniu niepełnosprawności wzrokowej. Osoby ze znacznym stopniem dysfunkcji wzroku są specyficzną grupą na rynku pracy, zmagającą się z różnego rodzaju barierami i trudnościami. Jedni niewidomi radzą sobie w życiu lepiej inni gorzej, a koncepcja kapitału społecznego może to po części tłumaczyć. Jeśli dysponują oni bogatą siecią społecznych kontaktów, w której skład wchodzą osoby posiadające różnego rodzaju zasoby, to mogą liczyć w różnych sytuacjach na pomoc z ich strony. Wsparcie osób z niepełnosprawnością, w tym rehabilitacja społeczna i zawodowa oraz ich zatrudnianie jest ważnym i wciąż poruszanym spo-
\end{abstract}


Joanna Kapias - Kapitał społeczny osób niewidomych...

łecznym tematem. Spojrzenie nań przez pryzmat kapitału społecznego w mojej opinii może zaowocować nową perspektywą.

Słowa kluczowe: niepełnosprawność, osoby niewidome, kapitał społeczny, rehabilitacja zawodowa

\begin{abstract}
:
This article is a part of the research conducted as part of the Master's thesis with the same title defended in 2017 at the Department of Ethnology and Educational Sciences in Cieszyn, University of Silesia in Katowice. The promoter of this work was prof. $\mathrm{dr}$ hab. Zenon Gajdzica. The article is devoted to the social capital of people with significant visual disability and their professional situation. In my research, I set a goal for the diagnosis of the social capital of the blind in the productive age and to examine the relationship between it and the occupational situation of these people. In my research, I used the concept of Individual Social Capital, according to which it is an asset of an individual. According to the literature, I assume that Social Capital may condition the professional activity of people with disabilities, including blind people. In this work, blind people are considered to be people with a severe visual impairment certificate. People with a significant degree of vision dysfunction are a specific group on the labor market, which is struggling with various barriers and difficulties. Some people do better in life than others, and the concept of Social Capital can explain it in part. People with a rich network of social contacts, including people with various assets, can count on help from these people in different situations. Support for people with disabilities, including social and vocational rehabilitation and employment of these people is an important and still discussed social topic. Looking at it from the perspective of Social Capital may in my opinion lead to a new perspective.
\end{abstract}

Keywords: disability, blind people, social capital, occupational rehabilitation

\title{
1. Podstawowe zagadnienia z zakresu niepełnosprawności wzroku
}

Wzrok często uznawany jest za jeden z najważniejszych zmysłów człowieka. Według różnych źródeł dostarcza on człowiekowi 75-90\% informacji o świecie ${ }^{1}$. Zapewnia on człowiekowi m. in. poczucie bezpieczeństwa, ponieważ znacznie szybciej niż inne zmysły ostrzega

\footnotetext{
1 http://www.tea.org.pl/userfiles/file/Seminaria/niepelnosprawnosc_wzrokowa _wzrokowo_sluchowa_mksiazek.pdf [dostęp: 03-11-2016].
} 
przed zbliżającym się zagrożeniem² ${ }^{2}$ Według Światowej Organizacji Zdrowia (WHO) liczba osób na świecie z wadami wzroku może wynosić nawet 135 milionów. Liczba ludzi niewidomych wciąż rośnie i obecnie szacuje się ją w granicach 40-45 milionów osób³ Jak wynika z badań statystycznych GUS, w Polsce zarówno w 2004 roku4, jak i w $2009^{5}$ niepełnosprawność wzroku była czwartą przyczyną niepełnosprawności ${ }^{6}$. Analizując dane statystyczne, należy pamiętać, że w badaniach GUS do grona osób niewidomych zaliczane są również osoby ociemniałe, czyli takie, które utraciły zdolność widzenia po piątym roku życia7.

Przyczyny wad wzroku mogą mieć różne podłoże i można je sklasyfikować w następujący sposób8:

- spowodowane czynnikami genetycznymi (dziedziczny zanik nerwu wzrokowego, dziedziczna zaćma, dziedzicznie wysoka krótkowzroczność);

- spowodowane czynnikami wrodzonymi - powstałymi w czasie życia płodowego (wiążą się one z chorobami, jakie przechodziła matka w trakcie trwania ciąży, np. kiła, odra, różyczka, toksoplazma);

- choroby oczu (np. jaskra, zaćma, jaglica, barwnikowe zwyrodnienie siatkówki, nowotwory oka);

2 J. Konarska, Formy wsparcia rehabilitacji osób z niepełnosprawnościq wzrokowq, [w:] B. Grochmal-Bach, M. Alberska, A. Grzebionga (red.), Wspomaganie funkcjonowania psychospołecznego osób z niepełnosprawnością, Kraków 2013, s. 47-48.

3 http://www.who.int/mediacentre/news/releases/2003/pr73/en/ [dostęp: 0111-2016].

${ }^{4} \mathrm{http}$ //stat.gov.pl/cps/rde/xbcr/gus/stan_zdrowia_2004.pdf [dostęp: 01-11-2016]. 2016].

$5 \mathrm{http}: / /$ stat.gov.pl/cps/rde/xbcr/gus/ZO_stan_zdrowia_2009.pdf [dostęp: 01-11-

6 Informacja Rzq̨du Rzeczypospolitej Polskiej o działaniach podejmowanych w 2009 roku na rzecz realizacji postanowień uchwały Sejmu Rzeczypospolitej Polskiej z dnia 1 sierpnia 1997 „Karta praw osób niepełnosprawnych”, Warszawa 2010, s. 3-4.

7 T. Majewski, Psychologia niewidomych i niedowidzących, Warszawa 1985, s. 175.

8 T. Majewski, Poradnik metodyczny dla nauczycieli pracujących z dziećmi z uszkodzonym wzrokiem w systemie integracyjnym, Lublin 1997, s. 15-16. 
Joanna Kapias - Kapitał społeczny osób niewidomych...

- choroby ogólne, które mogą powodować uszkodzenie narządu wzroku (np. cukrzyca, gruźlica, zapalenie opon mózgowych i mózgu);

- awitaminoza (dieta uboga w witaminę A);

- różnego rodzaju urazy mechaniczne w wyniku wypadków, uderzeń itp.

Zgodnie z przepisami polskiego prawa niewidomą jest osoba, która posiada orzeczenie o niepełnosprawności wzroku w stopniu znacznym. Przy kwalifikowaniu niepełnosprawności spowodowanej dysfunkcją wzroku bierze się pod uwagę pole i ostrość widzenia po korekcji szkłami korekcyjnymi. Stopień niepełnosprawności orzeka się wobec osób powyżej 16 roku życia. Do jednego z trzech stopni niepełnosprawności (znaczny, umiarkowany, lekki) kwalifikuje się osoby, które posiadają „choroby narządu wzroku, w tym wrodzone lub nabyte wady narządu wzroku powodujące ograniczenie jego sprawności, prowadzące do obniżenia ostrości wzroku w oku lepszym do 0,3 według Snellena po wyrównaniu wady wzroku szkłami korekcyjnymi lub ograniczenie pola widzenia do przestrzeni zawartej w granicach 30 stopni". Choroby narządu wzroku w orzeczeniach oznaczone są kodem 04-09.

Niepełnosprawność wzroku powoduje różnego rodzaju konsekwencje, które można zaklasyfikować jako fizyczno-zdrowotne, orientacyjno-poznawcze oraz psychospołeczne (szereg nieprawidłowych postaw poznawczych emocjonalnych i społecznych) ${ }^{10}$. Nie będę opisywała wszystkich trudności, z jakimi zmagają się osoby z niepełnosprawnością wzroku, gdyż jest to temat bardzo obszerny. Skupię się jedynie na tych, które związane są z sytuacją osób niewidomych na rynku pracy.

\footnotetext{
${ }^{9}$ Rozporządzenie Ministra Gospodarki, Pracy i Polityki Społecznej z dnia 15 lipca 2003 (z późn. zm.), w sprawie orzekania o niepełnosprawności i stopniu niepełnosprawności, Załącznik do obwieszczenia Ministra Pracy i Polityki Społecznej z dnia 8 lipca 2015 r. (poz. 1110), § 32

10 R. Ossowski, Pedagogika niewidomych i niedowidzących, [w:] W. Dykcik (red.), Pedagogika Specjalna, Poznań 1997, s. 159-168.
} 
Według danych Polskiego Związku Niewidomych w latach 20092010 18\% niewidomych członków PZN w wieku produkcyjnym było aktywnymi zawodowo ${ }^{11}$. Największa liczba osób z niepełnosprawnością wzroku będących członkami PZN-u w 2010 roku pracowała w prywatnych przedsiębiorstwach (25\%). Kolejne najczęstsze miejsca pracy tych osób to zakłady pracy chronionej (19\%) oraz instytucje państwowe i samorządowe (16\%). Spora część tychże osób prowadzi własną działalność gospodarczą (9\%). Najczęściej wg danych PZN osoby z niepełnosprawnością wzroku zatrudniane są jako pracownicy administracyjno-biurowi (11\%), masażyści i fizjoterapeuci (11\%), a także portierzy i ochroniarze $(9 \%)^{12}$. Należy pamiętać, że wszystkie powyższe dane odnoszą się do członków Polskiego Związku Niewidomych. Biorąc pod uwagę, że PZN posiada 65 tys. Członków, 18\% z tej liczby to zaledwie 11700 osób, a po wprowadzeniu kryterium wieku produkcyjnego wynik byłby jeszcze niższy (członkami PZN są również dzieci i osoby starsze). Nieznane są również dane na temat zatrudnienia osób niewidomych i słabowidzących niebędących członkami PZN.

Osoby z niepełnosprawnością wzroku w mojej opinii są na rynku pracy wciąż niezauważane jako potencjalnie wartościowi pracownicy. Na polskim rynku niewiele jest literatury związanej z funkcjonowaniem osób z niepełnosprawnością wzroku oraz z ich rehabilitacją społeczną i zawodową. Uważam, że prowadzi się niewiele działań praktycznych związanych z rehabilitacją tej grupy osób, a pod kątem badań teoretycznych jest to obszar pełen niewiadomych. Sama rehabilitacja społeczna i zawodowa jest w mojej ocenie realizowana w nieprzemyślany, chaotyczny i nie zawsze skuteczny sposób. 0 ile osoby niewidome od urodzenia są rehabilitowane w systemowy, spójny

${ }^{11}$ E. Łukasiak, E. Oleksiak, Osoby niewidome i niedowidzace, [w:] Zbiorczy raport z diagnozy świadczonych usług z zakresu rehabilitacji społecznej dla osób niepełnosprawnych w Polsce, Warszawa 2011, s. 16, http://www.koalicjaon.org.pl/photo/ File/projekt_standardy/raport_zbiorczy_z_diagnozy_swiadczonych_uslug_rehabilitac yjnych.pdf [dostęp: 05-11-2016].

12 Ibidem, s. 16-17. 
Joanna Kapias - Kapitał społeczny osób niewidomych...

sposób w trakcie edukacji, o tyle osoby nowo ociemniałe są bardzo często pozostawione same sobie. Przypuszczam, że osoby z niepełnosprawnością znajdują dużo częściej zatrudnienie dzięki swoim sieciom kontaktów, a nie np. za pośrednictwem urzędów pracy. W swoich badaniach chcę posłużyć się kategorią kapitału społecznego, którą opiszę w następnej części artykułu.

\section{Teorie kapitału społecznego}

Analizując liczne opracowania naukowe z zakresu ekonomii, polityki, a także socjologii posługujące się pojęciem kapitału społecznego, można dość do wniosku, że niemal każdy autor rozumie przez nie coś innego. Posługując się językiem logiki, można zaryzykować stwierdzenie, że pod nazwą kapitał społeczny ukrywa się wiele różnych desygnatów.

Pojęcie kapitał rozumiane jest jako zasób, który „daje lub może dać zysk"13.

Kategoria kapitału społecznego po raz pierwszy została użyta w kontekście rozważań nad ideą demokracji, a konkretniej partycypacji i oznaczała wówczas zasoby, jakie przysługiwały jednostce ${ }^{14}$. Powszechnie pojęcie kapitału społecznego kojarzone jest z relacjami międzyludzkimi15 i ma swoje zastosowanie praktyczne m.in. w naukach ekonomicznych.

Według Piotra Milkiewicza podstawą „współczesnego dyskursu teoretycznego na temat kapitału społecznego są dwa bieguny w postaci teorii Pierre'a Bourdieu i teorii Jamesa Colemana"16. Natomiast Cezary Trutkowski i Sławomir Mandes poza tymi dwoma perspekty-

13 B. Niemierko, Jak mierzyć kapitał ludzki i kapitał społeczny? Edukacyjne perspektywy operacjonalizacji pojęć ekonomicznych, „Zeszyty Naukowe Akademii Marynarki Wojennej" 2011, nr 4, s. 257.

14 W. Bokajło, Amerykańskie korzenie kapitału społecznego, [w:] M. Klimowicz, W. Bokajło (red.), Kapitał społeczny - interpretacje, impresje, operacjonalizacja, Warszawa 2010, s. 19.

15 P. Mikiewicz, Kapitał społeczny i edukacja, Warszawa 2014, s. 66.

16 Ibidem, s. 183. 
wami teoretycznymi wymieniają za Thedą Skocpol trzecią, w którą wpisują się prace Roberta Putnama. Wszystkie trzy koncepcje wywodzą się z zupełnie różnych (a czasami sprzecznych) przesłanek ${ }^{17}$. Autorzy opracowań teoretycznych wśród wiodących koncepcji kapitału społecznego wymieniają również prace Francisa Fukuyamy. W swojej pracy posługuję się koncepcją indywidualnego kapitału społecznego, skupię się zatem jedynie na koncepcji Pierre'a Bourdieu. Zagadnienie to jest dość obszerne i postaram się przedstawić skrótowo jedynie najważniejsze związane z nim kwestie.

\subsection{Koncepcja kapitału społecznego Pierre’a Bourdieu}

Definicja kapitału społecznego została wprowadzona do literatury socjologicznej przez francuskiego socjologa, antropologa i filozofa Pierre'a Bourdieu w latach 70. XX w. ${ }^{18}$. Jego analiza koncepcji kapitału społecznego była pierwszą współczesną pracą dotyczącą tego tematu. Opublikowana została ona w języku francuskim i nie dotarła do krajów anglojęzycznych, przez co często za twórcę pierwszej analizy kapitału społecznego niektórzy teoretycy podają Jamesa Colemana ${ }^{19}$. Koncepcja Bourdieu jest ugruntowana w teorii władzy symbolicznej oraz teorii reprodukcji społecznej ${ }^{20}$ Koncepcja ta jest oparta na perspektywie indywidualistycznej i fundamentalne dla niej jest założenie, że powiązania społeczne są rodzajem zasobu, który może przynosić grupom i jednostkom różnego rodzaju korzyści. ${ }^{21}$.

Zasoby jednostek i grup mogą być rzeczywiste lub wirtualne, mogą być dziedziczone lub zdobyte dzięki własnemu trudowi i wpisują się w mniej lub bardziej zinstytucjonalizowaną formę relacji społecz-

17 C. Trutkowski, S. Mandes, Kapitał Społeczny w małych miastach, Warszawa 2005, s. 48.

18 M. Radoła, Kapitał społeczny, a osiagnięcia szkolne ucznia, „Studia Edukacyjne” 2013, nr 27, s. 144.

${ }^{19}$ A. Rymsza, Klasyczne koncepcje kapitału społecznego, [w:] T. Kaźmierczak, M. Rymsza (red.), Kapitał Społeczny Ekonomia społeczna, Warszawa 2007, s. 24.

20 P. Mikiewicz, Kapitał społeczny i edukacja..., op. cit., s. 183.

21 J. Działek, Kapitał społeczny jako czynnik rozwoju gospodarczego w skali regionalnej i lokalnej w Polsce, Kraków, 2011, s. 16. 
Joanna Kapias - Kapitał społeczny osób niewidomych...

nych ${ }^{22}$. Bourdieu wymienia cztery wzajemnie ze sobą powiązane typy kapitałów ${ }^{23}$.

Kapitał ekonomiczny. To głównie poziom otrzymywanego za pracę wynagrodzenia z uwzględnieniem tego, czy praca ta jest fizyczna czy umysłowa. Kapitał ten mierzy się w stosunku do kapitału ekonomicznego rodziny.

Kapitał kulturowy (nazywany też informacyjnym). Występuje w następujących formach:

- ucieleśniony - funkcjonuje na zasadzie asymilacji wartości, postaw w procesie socjalizacji;

- zobiektywizowany - dobra kulturowe, takie jak obrazy, książki, urządzenia, instrumenty (mierzony nie tylko ich posiadaniem, ale też częstotliwością użytkowania);

- zinstytucjonalizowany - występujący jako akademickie kwalifikacje, które oficjalnie gwarantują posiadane kompetencje i nie wymagają ich udowadniania (w przeciwieństwie do innych form kapitału).

Francuski socjolog przyjął, iż wszystkie „działania społeczne rozgrywają się w społecznie skonstruowanych polach interakcji”, w których „aktorzy” posiadający różnego rodzaju zasoby wykorzystują je „w grze z innymi aktorami w celu uzyskania przewagi”. Człowiek dzięki swojej zdolności do interpretacji świata oraz działania może rozpoznawać zarówno pole interakcji, jak i zasoby (kapitały) swoje i innych ludzi. Interpretacje oraz realny poziom zasobów zależne są od pozycji społecznej oraz cech danej jednostki. Kapitał jest zatem ściśle związany ze środowiskiem rodzinnym, a także otoczeniem, w którym ona funkcjonuje24.

Kapitał społeczny jest definiowany przez Bourdieu jako suma „rzeczywistych oraz potencjalnych zasobów, które związane są z posiada-

\footnotetext{
22 J. Przybyś, J. Sauś, Kapitał społeczny. Szkice socjologiczno-ekonomiczne, Poznań 2004, s. 12.

23 P. Mikiewicz, Kapitał społeczny i edukacja, op. cit., s. 93-107.

24 Ibidem, s. 98.
} 
niem trwałej sieci mniej lub bardziej zinstytucjonalizowanych związków opartych na wzajemnej znajomości i uznaniu"25. Bycie członkiem grupy umożliwia otrzymanie od pozostałych członków wsparcia, jakim jest kapitał posiadany przez kolektyw oraz wiarygodność ${ }^{26}$. Oznacza to, że dzięki wzajemnemu zaufaniu członków grupy jednostka ma dostęp do kapitału posiadanego przez wszystkich. Należy więc pamiętać, że w ujęciu P. Bourdieu kapitał społeczny składa się nie tylko z samej relacji, ale również z zasobów dostępnych dzięki tej relacji, np. członkostwo w dużej grupie, która posiada gęstą sieć powiązań, nie zmieni w sposób znaczący sytuacji jednostki, jeżeli ludzie tworzący grupę nie będą dysponować dużymi środkami materialnymi lub wiedzą (wykształceniem), którą jednostka mogłaby wykorzystać do poprawy swojej sytuacji ${ }^{27}$. Zatem zasób kapitału społecznego jednostki zależny jest od dwóch czynników, mianowicie od:

1. wielkości sieci, którą jednostka potrafi zmobilizować;

2. zakresu kapitału jednostek w sieci, z którymi dana osoba jest powiązana $^{28}$.

Zwrócić należy również uwagę na kapitał symboliczny, bardzo silnie powiązany z pojęciem prestiżu. Posiadanie pewnych kompetencji w środowisku, gdzie niewiele osób nimi dysponuje, powoduje, że osoba je posiadająca zyskuje „przewagę”. Taka osoba może zająć wyższą pozycję społeczną oraz wykorzystując kapitał symboliczny, zwiększać swój kapitał ekonomiczny.

\subsection{Kapitał społeczny osób z niepełnosprawnościq}

Niewiele jest badań, które w sposób jednoznaczny określają cechy kapitału społecznego w odniesieniu do osób z niepełnosprawnością. Kapitał społeczny ogólnie uznawany jest jako „potencjał społeczeństwa i jednostek." Przejawia się on w tworzonych przez ludzi instytu-

\footnotetext{
${ }^{25}$ A. Rymsza, Klasyczne koncepcje kapitału..., op. cit., s. 24.

26 E. Skawińska, Kapitał społeczny w rozwoju regionu, Warszawa 2012, s. 15.

27 J. Działek, Kapitał społeczny jako czynnik rozwoju..., op. cit., s. 16.

${ }^{28}$ A. Rymsza, Klasyczne koncepcje..., op. cit., s. 24.
} 
Joanna Kapias - Kapitał społeczny osób niewidomych...

cjach, a także wartościach, normach i wzorach zachowań. Wszystkie te elementy tworzą podstawę „dla zachowań społecznych, opierając się na zaufaniu." Według W. Dykcika wśród osób niepełnosprawnych można zauważyć lęki i niepokoje wynikające z niskiego poziomu zaufania ${ }^{29}$. Należy pamiętać jednak o szerszym kontekście. Według badań Polacy są narodem raczej nieufnym. Tylko 23\% Polaków uważa, iż większości ludzi można ufać ${ }^{30}$. W związku z tym wśród osób niepełnosprawnych można spodziewać się jeszcze niższego poziomu zaufania społecznego z powodu doznanych przez te osoby różnego rodzaju krzywd. Nie dotarłam jednak do badań na temat poziomu zaufania wśród osób z niepełnosprawnością.

Według badań osoby z niepełnosprawnością często wykazują również trudności w zakresie kompetencji społecznych. Niedostatki te mogą „utrudniać budowanie sieci społecznych”, a także znalezienie pracy czy zorganizowanie sobie samozatrudnienia ${ }^{31}$. W literaturze można znaleźć badania dotyczące osób z niepełnosprawnością w kontekście kapitału społecznego, np. w odniesieniu do pracy w spółdzielniach socjalnych ${ }^{32}$ lub w kontekście wykluczenia społecznego ${ }^{33}$.

Kapitał społeczny może warunkować aktywność zawodową osób z niepełnosprawnością ${ }^{34}$. W moich badaniach będę się posługiwała pojęciem kapitału społecznego w rozumieniu indywidualnym. Posta-

29 E. Bogacz-Wojtanowska, Partycypacja społeczna (w tym polityczna) osób niepełnosprawnych UE/EOG oraz sytuacja w Polsce. Przesłanki prawne i społeczne upodmiotowienia środowisk osób niepełnosprawnych, http://polscyniepelnosprawni.agh.edu.pl/ wp-content/uploads/1_3_06_2_raport_ekspercki_analiza_porownawcza_UE_PL_modul _I_Bogacz_Wojtanowska.pdf [dostęp: 19-11-2016], s. 86.

30 Komunikat z badań: Zaufanie społeczne, BS/33/2012, Centrum Badania Opinii Społecznej, Warszawa 2012. s. 86.

31 E. Bogacz-Wojtanowska, Partycypacja społeczna (w tym polityczna)..., op. cit.,

32 P. Wróbel, Rola i znaczenie kapitału społecznego w spółdzielniach socjalnych analiza empiryczna wymiarów kapitału, www.delibra.bg.polsl.pl/Content/27299/ BCPS_31023_-_Rola-i-znaczenie-kap_0000.pdf [dostęp: 19-11-2016].

${ }_{33}$ I. Fajfer-Kruczek, Wykluczenie społeczne osób z niepełnosprawnościq w środowisku lokalnym, Katowice 2015.

${ }^{34}$ A. I. Brzezińska, R. Kaczan, K. Piotrowski, P. Rycielski, Uwarunkowania aktywności zawodowej osób z ograniczeniami sprawności: kapitał osobisty i społeczny, „Nauka” 2009, nr 2, s.129-156. 
ram się wykazać, że osoby z niepełnosprawnością z wysokim kapitałem społecznym, tzn. dużą siecią relacji społecznych nacechowanymi wzajemnym wsparciem i zaufaniem, lepiej radzą sobie w życiu zawodowym. Chcąc wykazać tę zależność, należy również zmierzyć pochodną kapitału społecznego, jaką jest kapitał ludzki. Przez kapitał ludzki będę rozumiała wiedzę, umiejętności i zdolności osób badanych. W związku z tym w badaniach uwzględnię poziom wykształcenia oraz wiedzę i umiejętności, które mają znaczenie dla aktywności zawodowej35. Uważam, że zbadanie zależności pomiędzy kapitałem społecznym osób z niepełnosprawnością wzroku a ich sytuacją zawodową umożliwi efektywniejsze działania w zakresie rehabilitacji społecznej i zawodowej tychże osób.

\section{Metodologia badań własnych}

Przedmiotem moich badań będzie kapitał społeczny osób niewidomych $\mathrm{w}$ wieku produkcyjnym, ich sytuacja zawodowa oraz zależność pomiędzy nimi. W swoich badaniach za cel postawiłam sobie diagnozę kapitału społecznego osób niewidomych w wieku produkcyjnym oraz zbadanie zależności pomiędzy nim a sytuacją zawodową tychże osób.

Główny problem badawczy w niniejszej pracy sformułowałam następująco: Jaka jest zależność pomiędzy kapitałem społecznym osób niewidomych $\mathrm{w}$ wieku produkcyjnym a ich sytuacją zawodową? Z wyżej przedstawionego problemu badawczego wynikają poniższe problemy szczegółowe:

1. Jaki jest kapitał społeczny osób niewidomych w wieku produkcyjnym?

2. Jaka jest sytuacja zawodowa osób niewidomych w wieku produkcyjnym?

35 Pentor Research International, Badania wpływu kierunku i poziomu wykształcenia na aktywność zawodowa osób niepełnosprawnych - Raport końcowy, www.pfron.org.pl/ftp/dokumenty/Badania_i_analizy/Raport_CZESC_1z6_final.pdf [dostęp: 19-11-2016]. 
Joanna Kapias - Kapitał społeczny osób niewidomych...

W świetle literatury, którą przytoczyłam oraz problemu badawczego wysnułam hipotezę główną: Kapitał społeczny osób niewidomych $\mathrm{w}$ wieku produkcyjnym ma związek $\mathrm{z}$ ich sytuacją zawodową. Uważam, że im większy kapitał społeczny danej osoby, tym lepsza jest jej sytuacja na rynku pracy. Można założyć, że osoby te mogą łatwiej znaleźć pracę dzięki sieci kontaktów, jakie posiadają oraz wykorzystać je do rozwiązywania różnego rodzaju problemów. Ponadto większy kapitał ludzki, uznany przeze mnie za komponent kapitału społecznego, czyli wyższe kompetencje zawodowe, wykształcenie, ukończone kursy, szkolenia oraz doświadczenie zawodowe są elementami istotnymi na rynku pracy. Uważam również, że działalność w różnego rodzaju organizacjach, korzystanie $\mathrm{z}$ oferty turystycznej i kulturalnej, turnusów rehabilitacyjnych i innych form rehabilitacji społecznej i zawodowej świadczy o dużej sieci kontaktów społecznych, samodzielności i zaradności danej osoby.

W swoich badaniach posłużyłam się metodą sondażu diagnostycznego. Dane zebrałam za pomocą ankiety własnego autorstwa oraz za pomocą Kwestionariusza do Pomiaru Indywidualnego Kapitału Społecznego (KPIKS). W badaniach posłużyłam się zmiennymi i wskaźnikami opisanymi w Tabeli 1 (na następnej stronie).

Badanie ankietowe polega na wypełnieniu kwestionariusza przez osobę badaną. Charakterystyczną cechą tych badań jest wysoki poziom standaryzacji. Pytania w ankiecie są ścisłe, konkretne i jednoproblemowe. Najczęściej ankiety zawierają pytania zamknięte z gotowym zestawem odpowiedzi do wyboru, czyli tzw. kafeterią. W badaniach pedagogicznych ankieta jest popularnym narzędziem umożliwiającym pozyskanie informacji o cechach zbiorowości, faktach, opiniach o zdarzeniach itp. ${ }^{36}$.

36 T. Pilch, T. Bauman, Zasady badań pedagogicznych. Strategie ilościowe $i$ jakościowe, Warszawa 2001, s. 96-97. 
Tabela 1. Zmienne i wskaźniki zastosowane w badaniach własnych

\begin{tabular}{|c|c|}
\hline \multicolumn{2}{|c|}{$\begin{array}{l}\text { Problem główny: } \\
\text { Jaki jest związek pomiędzy kapitałem społecznym a sytuacją zawodową dorosłych } \\
\text { osób niewidomych w wieku produkcyjnym? }\end{array}$} \\
\hline $\begin{array}{c}\text { Zmienna zależna: } \\
\text { Sytuacja zawodowa dorosłych osób } \\
\text { niewidomych }\end{array}$ & $\begin{array}{l}\text { Zmienna niezależna: } \\
\text { Indywidualny kapitał społeczny dorosłych } \\
\text { osób niewidomych }\end{array}$ \\
\hline Wskaźniki zmiennej zależnej & Wskaźniki zmiennej niezależnej \\
\hline $\begin{array}{l}\text { - deklaracje na temat obecnej aktywności } \\
\text { zawodowej (fakt pracy lub jej brak), } \\
\text { - deklaracje osób pracujących na temat wy- } \\
\text { konywanej pracy (wykonywany zawód, } \\
\text { forma zatrudnienia, miejsce zatrudnienia, } \\
\text { sposób znalezienia pracy, zadowolenie } \\
\text { z wykonywanej pracy), } \\
\text { - deklaracje osób pracujących i niepracują- } \\
\text { cych na temat sposobu pozyskiwania infor- } \\
\text { macji o ofertach pracy, } \\
\text { - deklaracje osób bezrobotnych na temat sy- } \\
\text { tuacji zawodowej (chęć podjęcia pracy, } \\
\text { sposoby poszukiwania pracy, czas pozosta- } \\
\text { wania bez pracy) }\end{array}$ & $\begin{array}{l}\text { Wynik ogólny testu KPIKS-20, } \\
\text { - wielkość sieci kontaktów, } \\
\text { - deklarowany poziom zaufania względem } \\
\text { innych ludzi, } \\
\text { - deklaracje na temat działalności w organi- } \\
\text { zacjach społecznych, } \\
\text { - deklaracje na temat udziału w zajęciach } \\
\text { w Warsztacie Terapii Zajęciowej, pracy } \\
\text { w Zakładzie Aktywności Zawodowej, } \\
\text { - poziom wykształcenia, } \\
\text { - ukończone kursy i szkolenia, } \\
\text { - deklarowane kompetencje w zakresie } \\
\text { technologii informacyjnej, } \\
\text { - doświadczenie zawodowe, } \\
\text { - deklarowane cechy pożądane na rynku } \\
\text { pracy (np. punktualność, dyspozycyjność, } \\
\text { samodzielność, kreatywność, umiejętności } \\
\text { organizacyjne) }\end{array}$ \\
\hline
\end{tabular}

Źródło: Opracowanie własne.

Drugim sposobem pozyskania przeze mnie danych jest kwestionariusz KPIKS oparty na idei generatora zasobów Toma Snijdersa. Narzędzie zostało stworzone w dwóch wersjach. Wersja KPIKS-60 obejmuje 60 pozycji testowych, natomiast KPIKS-20 zawiera 20 pytań. Wszystkie pytania są skonstruowane w ten sam sposób i zaczynają się od formuły „Czy znasz kogoś, kto...”, następnie w każdym pytaniu wymieniona jest osoba o jakiejś umiejętności, posiadająca jakiś zasób itp. Badany zaznacza na czterostopniowej skali informację o tym, czy i jak dobrze zna taką osobę. Surowe wyniki kwestionariusza są inter- 
Joanna Kapias - Kapitał społeczny osób niewidomych...

pretowane względem norm stenowych, np. wynik od 1 do 3 charakteryzuje osobę, która posiada niski indywidualny kapitał społeczny. Dokładne normy dla obu testów prezentuję w tabeli poniżej37.

Tabela 2. Normy stenowe dla KPIKS-20 i KPIKS-60 przeprowadzone na grupie studentów $\mathrm{N}=120$

\begin{tabular}{|c|c|c|}
\hline Sten & $\begin{array}{c}\text { Wynik surowy } \\
\text { KPIKS-20 }\end{array}$ & $\begin{array}{c}\text { Wynik surowy } \\
\text { KPIKS-60 }\end{array}$ \\
\hline $\mathbf{1}$ & do 52 & do 143 \\
\hline $\mathbf{2}$ & $53-56$ & $144-159$ \\
\hline $\mathbf{3}$ & $57-62$ & $160-174$ \\
\hline $\mathbf{4}$ & $63-68$ & $171-186$ \\
\hline $\mathbf{5}$ & $69-72$ & $187-195$ \\
\hline $\mathbf{6}$ & $73-75$ & $196-208$ \\
\hline $\mathbf{7}$ & $76-78$ & $209-216$ \\
\hline $\mathbf{8}$ & $79-80$ & $217-227$ \\
\hline $\mathbf{9}$ & $\mathrm{x}$ & powyżej 228 \\
\hline
\end{tabular}

Źródło: R. Styła, Kwestionariusz do Pomiaru Indywidualnego Kapitału Społecznego (KPIKS) - wstępna propozycja oparta na idei generatora zasobów Toma Snijdersa, „Psychologia Społeczna” 2009, tom 4, s. 67-77.

Należy jednak zaznaczyć, że normy były opracowywane na podstawie badań przeprowadzonych wśród grupy studentów, więc mogą być nieco inne niż normy dla osób z niepełnosprawnością. Nie dotarłam jednak do takiego zestawienia. Ponieważ chcę zmniejszyć ryzyko błędu związane z nie do końca adekwatnymi normami, w ankiecie mojego autorstwa znajdują się również pytania dotyczące poszczególnych komponentów kapitału społecznego.

Wyniki stenowe wg autora testu należy interpretować w następujący sposób:

37 R. Styła, Kwestionariusz do Pomiaru Indywidualnego Kapitału Społecznego (KPIKS) - wstępna propozycja oparta na idei generatora zasobów Toma Snijdersa, „Psychologia Społeczna” 2009, tom 4, s. 67-77. 
- Wynik 1-3 oznacza, iż osoba badana posiada niski poziom indywidualnego kapitału społecznego. Taka osoba, chcąc rozwiązać jakiś problem, prawdopodobnie będzie musiała skorzystać z bardziej formalnych form. Osoba ta, gdy na przykład będzie potrzebowała przetłumaczyć jakiś tekst z języka niemieckiego, z wysokim prawdopodobieństwem wynajmie tłumacza.

- Wynik 4-6 oznacza przeciętny poziom kapitału społecznego. Osoba posiadająca taki kapitał ma dostęp w swojej siatce społecznej do wielu atrakcyjnych zasobów. W niektórych przypadkach jednak zmuszona jest do pozyskiwania niektórych zasobów na ogólnie dostępnym rynku.

- Wynik 7-9 oznacza bardzo wysoki poziom kapitału. Dzięki rozbudowanej i bogatej w różnego rodzaju zasoby siatce społecznej osoba ta może uzyskać dostęp nawet do rzadkich zasobów.

Celem pozyskania możliwie największej liczby respondentów ankieta była prowadzona $\mathrm{w}$ różnych formach, tzn. internetowo, telefonicznie i $\mathrm{w}$ formie papierowej. Badania były prowadzone $\mathrm{w}$ marcu $2017 \mathrm{r}$

\section{Analiza badań własnych}

\subsection{Charakterystyka badanej grupy}

W badaniu wzięła udział grupa 67 osób ze znacznym stopniem niepełnosprawności wzrokowej będących jednocześnie w wieku produkcyjnym. Grupa jest niewielka, ponieważ trudno dotrzeć do wielu przedstawicieli tego środowiska, którzy zgodziliby się wypełnić dość obszerną w mojej opinii ankietę.

W badaniu wzięło udział 35 kobiet oraz 32 mężczyzn. Najmłodszy uczestnik miał 22 lata, natomiast najstarszy - 64. W związku z tym, że przedział wiekowy jest bardzo szeroki, zastosowałam podział wieku produkcyjnego - stosowany przez Główny Urząd Statystyczny - na wiek mobilny (18-44 rok życia) i wiek niemobilny (45-64 lata mężczyźni i 45-59 lat kobiety). Ze względu na wspomniany podział w ba- 
Joanna Kapias - Kapitał społeczny osób niewidomych...

daniu wzięło udział 37 osób w wieku mobilnym oraz 30 osób w wieku niemobilnym. W wyniku nałożenia na siebie powyższych dwu kryteriów okazało się, że w badaniu wzięły udział 23 kobiety w wieku mobilnym, 12 kobiet w wieku niemobilnym, 14 mężczyzn w wieku mobilnym oraz 18 mężczyzn w wieku niemobilnym.

W grupie respondentów znalazły się 4 osoby z wykształceniem podstawowym, $8 \mathrm{z}$ zawodowym, $15 \mathrm{z}$ wykształceniem średnim, 11 z technicznym oraz 28 z wykształceniem wyższym, jedna osoba nie udzieliła odpowiedzi na to pytanie.

Największa część osób badanych zamieszkuje duże miasta (pow. 100 tys. mieszkańców) i jest to 29 osób, następnie w miastach średnich (20 tys. - 100 tys. mieszkańców) mieszka 12 osób, w miastach małych (poniżej 20 tys. mieszkańców) 9 osób oraz 16 osób to mieszkańcy wsi.

\subsection{Kapitał społeczny badanej grupy - wynik generatora zasobów KPIKS-20}

Testy przeprowadzone za pomocą generatora zasobów KPIKS-20 wykazały, że 33 badanych posiada niski indywidualny kapitał społeczny, średni - 24, natomiast wysoki - 10 .

Wykres 1. Wyniki testu KPIKS-20 z uwzględnieniem wszystkich stenów

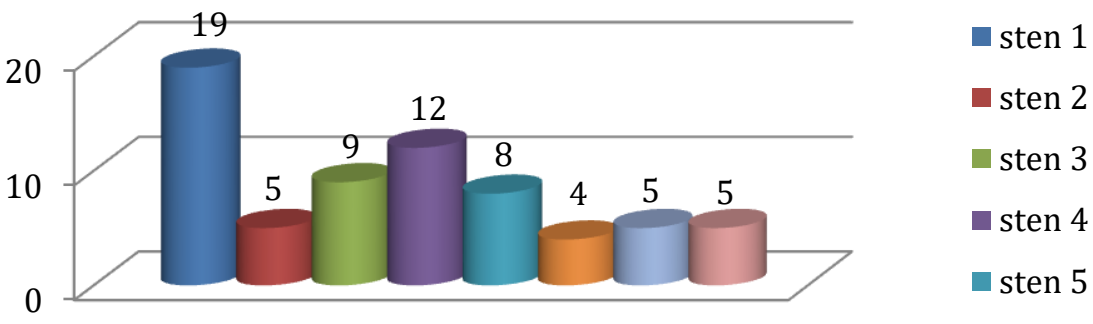

Źródło: Badania własne. 
Wykres 2. Wyniki testu KPIKS-20 z uwzględnieniem podziału na niski, średni i wysoki indywidualny kapitał społeczny (IKS)

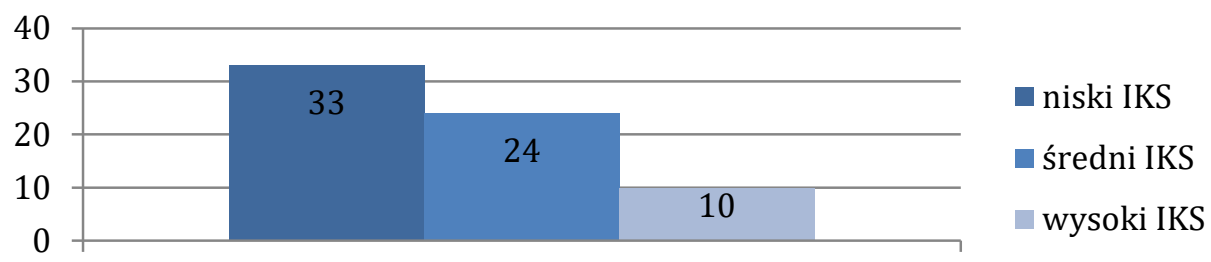

liczba osób

Źródło: Badania własne.

Analizując powyższy wykres, łatwo zauważyć, że najwięcej osób badanych dysponuje niskim IKS, natomiast najmniej wysokim. Grupa badawcza oczywiście nie jest reprezentatywna, lecz warto zaznaczyć fakt, iż niski IKS wśród osób ze znaczną niepełnosprawnością wzroku pojawia się znacząco częściej niż przeciętnie wśród ludzi pełnosprawnych. Zestawiając powyższe dane $\mathrm{z}$ danymi metrykalnymi, można zauważyć pewne zależności. Z badań wynika również, że ankietowane kobiety częściej niż mężczyźni posiadają wysoki poziom IKS, grupa badawcza jest jednak zbyt mała i zbyt różnorodna, aby można było ustalić, czy różnice te są istotne statystycznie. Można zauważyć również, że badane osoby w wieku niemobilnym (powyżej 44 roku życia) częściej dysponują wysokim indywidulanym kapitałem społecznym. Przyczyn takiego stanu rzeczy można doszukiwać się w tym, że w ciągu dłuższego życia osoby te miały więcej czasu na zawieranie różnego rodzaju znajomości. Pamiętać należy jednak, że nie każdy człowiek żyjący dłużej skorzystał z tej szansy i nawiązał liczne kontakty społeczne, część osób badanych w tym wieku posiada niski lub średni poziom IKS. 
Joanna Kapias - Kapitał społeczny osób niewidomych...

Wykres 3. Wyniki testu KPIKS-20 z uwzględnieniem poziomu wykształcenia osób badanych

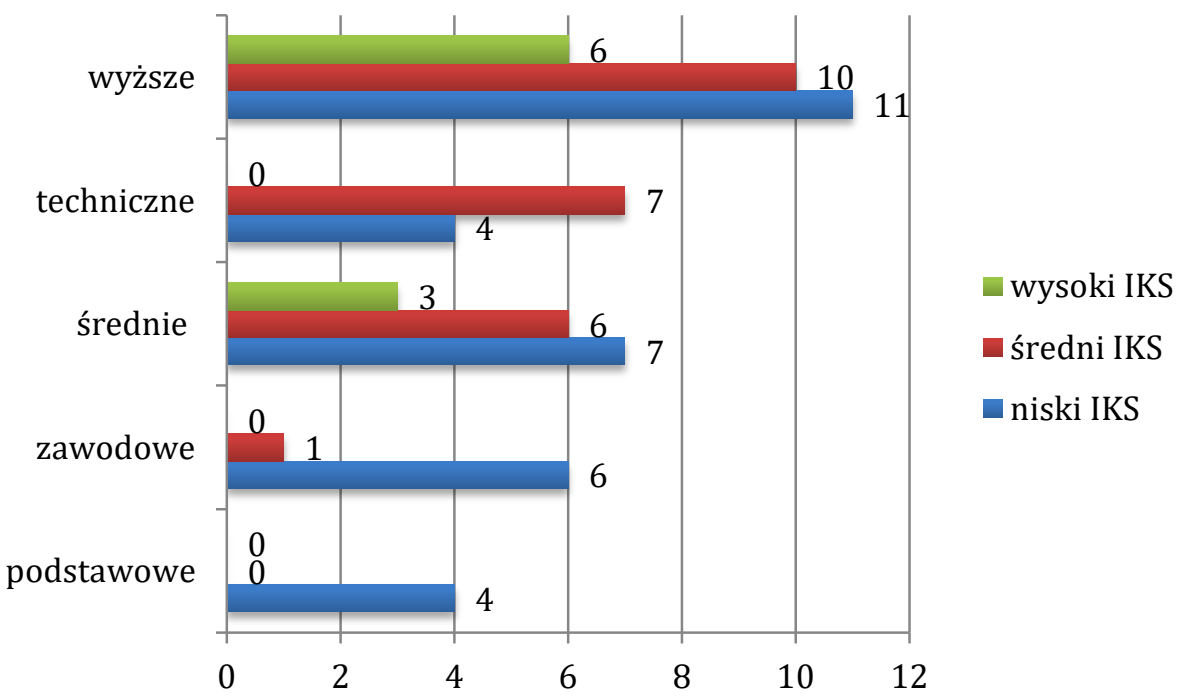

Źródło: Badania własne.

Wśród osób z wykształceniem podstawowym wszystkie osoby posiadały niski poziom IKS, a w grupie osób z wykształceniem zawodowym jedna osoba posiadała średni IKS, natomiast pozostałe niski. Wśród pozostałych kategorii wykształcenia wyniki były bardziej zróżnicowane i trudno zauważyć wyraźne tendencje. Zastanawiający jest jednak pewien fakt. Pomimo iż wśród osób z wyższym wykształceniem najwięcej osób w porównaniu do innych kategorii wykształcenia posiada wysoki IKS, to jednocześnie duża część tej grupy dysponuje niskim IKS (11 na 27). Można więc wnioskować, że wbrew pozorom wyższe wykształcenie nie gwarantuje wysokiego poziomu IKS.

\subsection{Kapitał społeczny grupy badanej - wyniki uzupełniające test generatora zasobów}

Celem uzupełnienia wyników testu mierzącego indywidualny kapitał społeczny badanym zadano dodatkowe pytania dotyczące ich rela- 
cji społecznych i innych komponentów kapitału społecznego, takich jak np. zaufanie ${ }^{38}$. Ze względu na obszerność zagadnień, jakie poruszałam w swojej pracy magisterskiej, tu przedstawię jedynie wybrane jej fragmenty.

Ze stwierdzeniem, że większości ludzi można ufać, zgodziło się 27 badanych, 14 nie miało zdania, natomiast 24 osoby nie zgodziły się $\mathrm{z}$ taką opinią. Dwie osoby nie udzieliły odpowiedzi. Po zestawieniu tych wyników z wynikami KPIKS-20 okazało się, że większość badanych osób z niskim poziomem indywidualnego kapitału społecznego nie zgadza się lub nie ma zdania w odniesieniu do opinii, że „większości ludzi można ufać”. Warto jednak zaznaczyć, że z powyższą opinią nie zgadzają się również niektóre osoby ze średnim i wysokim wynikiem IKS.

W jednym z kolejnych pytań respondenci zostali poproszeni o ustosunkowanie się do stwierdzenia „mam kogoś, na kogo zawsze mogę liczyć". Ze zdaniem tym zgodziła się większość respondentów, mianowicie 52 osoby, 7 osób nie miało zdania, natomiast 8 osób wybrało odpowiedź „nie zgadzam się”.

Kolejnym wskaźnikiem, który przyjęłam za swego rodzaju wyznacznik kapitału społecznego badanych, jest ich ogólne przekonanie o świecie. Opinia, do której respondenci mieli się ustosunkować, brzmiała „świat jest z natury zły”. Z tym stwierdzeniem zgodziło się 8 osób, 10 nie miało zdania. Znaczna większość, czyli 47 wybrało odpowiedź „nie zgadzam się”, natomiast 2 osoby nie udzieliły odpowiedzi. Wszystkie osoby, których wynik KPIKS-20 wskazywał na wysoki poziom indywidualnego kapitału społecznego, nie zgodziły się ze stwierdzeniem, jakoby świat był z natury zły. Im niższy poziom IKS, tym większa tendencja do skłaniania się $\mathrm{w}$ stronę takiej opinii lub brak ustosunkowania się do niej. Warto jednak zauważyć, że znaczna część osób z niskim IKS również nie zgodziła się z takim stwierdzeniem.

38 P. Mikiewicz, Kapitał społeczny i edukacja..., op. cit., s. 98. 
Joanna Kapias - Kapitał społeczny osób niewidomych...

Niezależnie od tego, czy zdajemy sobie z tego sprawę czy nie, to, jakie osoby znamy (nasza sieć kontaktów), ma istotne znaczenie przy rozwiązywaniu różnego rodzaju problemów ${ }^{39}$.

Kolejnym przytoczonym przeze mnie stwierdzeniem było zatem przekonanie, że „w życiu pomaga to, kogo się zna”. To pytanie jest w mojej opinii kwintesencją kapitału społecznego, jednak zadając to pytanie, obawiałam się, iż kojarzenie przez niektórych ludzi posiadania „znajomości” z czymś negatywnym mogłoby zniechęcać do zgodzenia się z takim stwierdzeniem. W związku z moimi obawami byłam zaskoczona, iż 46 osób zgodziło się z powyższym twierdzeniem, a 13 nie miało zdania. Ze stwierdzeniem tym nie zgodziło się 6 osób, natomiast jedna nie udzieliła odpowiedzi. Trudno zauważyć jakąś znaczącą relację pomiędzy poziomem IKS a opinią na ten temat. Przyczyn można doszukiwać się w fakcie, że przekonanie o tym, że „w życiu pomaga (lub nie) to, kogo się zna” nie świadczy o posiadaniu takich „znajomości”. Osoba, która posiada bardzo niski kapitał społeczny, nie zna wystarczająco dobrze ludzi, którzy w znaczący sposób mogliby pomóc jej w jakieś trudnej sytuacji, również może się z powyższą opinią zgadzać, np. odczuwając brak takich osób w swoim otoczeniu. Przedostatnie stwierdzenie, z którym badani się mogli zgodzić lub nie brzmiało „lubię poznawać nowych ludzi”. Z tą opinią zgodziła się znacząca większość, bo 57 osób. Odpowiedzi „nie mam zdania” udzieliły 4 osoby, a kolejne 4 wybrały opcję „nie zgadzam się”. Dwie osoby nie udzieliły odpowiedzi na powyższe pytanie.

Istotnym elementem budowania kapitału społecznego jest działalność w różnego rodzaju organizacjach typu stowarzyszenia, fundacje, koła, związki itp. ${ }^{40}$. Najczęściej wskazywaną organizacją przez osoby z niepełnosprawnością wzrokową jest Polski Związek Niewidomych. Są wśród badanych jednak osoby, które nie działają w żadnej organizacji lub działają w kilku jednocześnie.

\footnotetext{
39 A. Rymsza, Klasyczne koncepcje..., op. cit., s. 24.

40 J. Przybyś, J. Sauś, Kapitał społeczny..., op. cit., s. 11.
} 
Wykres 4. Działalność osób badanych w organizacjach pozarządowych

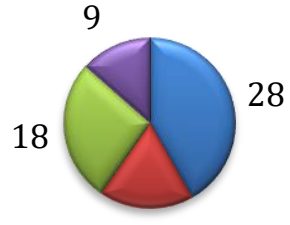

12 $\nabla 1$ organizacja

$\square \min .2$ organizacje

$\square$ brak odpowiedzi

$\square$ nie udzielają się

Źródło: Badania własne.

Wśród badanych w jednej organizacji udziela się 28 osób, a w więcej niż jednej 12. Pytanie to było często pomijane przez respondentów, ponieważ aż 18 osób nie udzieliło odpowiedzi (prawdopodobnie nie działając w żadnych organizacjach uznali, że wystarczy pytanie pominąć, aby dać temu wyraz). Do niedziałania w żadnych organizacjach przyznało się 9 badanych osób.

Osoby ze znaczną niepełnosprawnością wzroku czasami potrzebują pomocy osób widzących. Czasami jest to rodzina, znajomi, a innym razem wolontariusze lub zawodowi asystenci. Niektóre osoby twierdzą, że nie potrzebują pomocy. Analizując ten fragment ankiety, należy pamiętać, że są w Polsce miejscowości, w których nie ma dostępu do usług asystenckich czy wolontariuszy. Jako osobę spełniającą funkcję asystenta/przewodnika w życiu osób badanych 43 osoby wskazały członków rodziny, a 37 przyjaciół/znajomych. Zaledwie 10 osób korzysta z usług zawodowego asystenta, natomiast 4 osobom pomagają wolontariusze. Niewiele, bo 4 osoby, stwierdziły że chętnie skorzystałyby z takiej pomocy, ale nie mają takiej możliwości, Z kolei 6 osób zadeklarowało, że nie potrzebuje pomocy. W kwestionariuszu przy tym pytaniu była możliwość dopisania swojej odpowiedzi i takie odpowiedzi się pojawiły: jedną odpowiedź brzmiała „sąsiadka”, natomiast dwie pozostałe były bardziej przemyśleniami niż wskazaniem innych osób. 
Joanna Kapias - Kapitał społeczny osób niewidomych...

Wykres 5. Osoby, którzy pełnią funkcję asystenta/przewodnika badanych

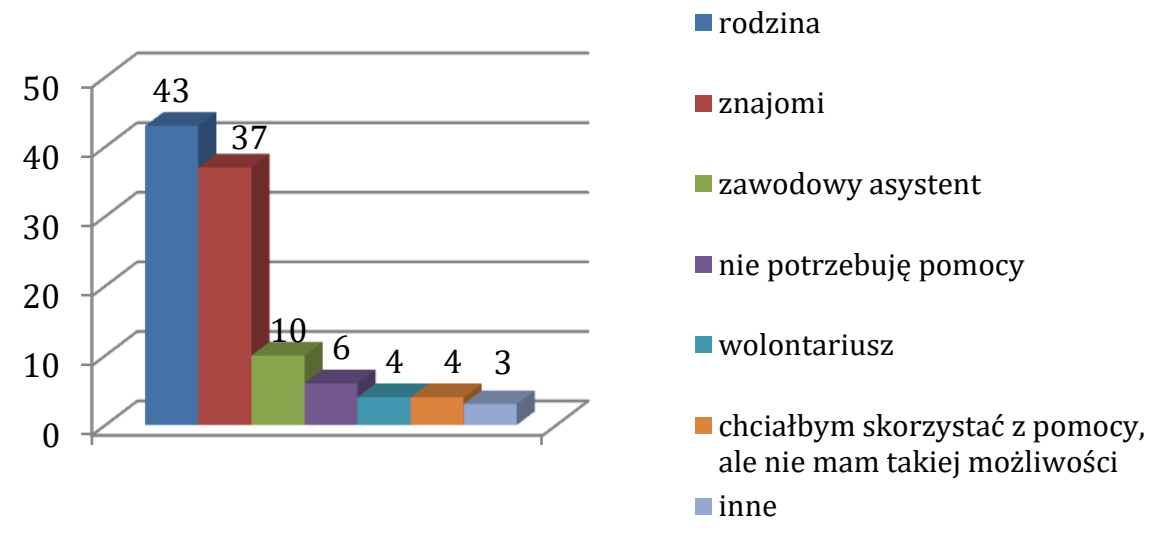

Źródło: Badania własne.

Wśród wszystkich grup najczęściej pojawiającą się odpowiedzią była rodzina, a następnie znajomi. Z perspektywy badań nad kapitałem społecznym istotne jest nie tylko, to, kto jest asystentem/przewodnikiem osób badanych, ale również to, ile odpowiedzi wskazali respondenci. Osoby z wysokim IKS prawdopodobnie mają więcej możliwości uzyskania pomocy. Jedna z badanych zwróciła moją uwagę na fakt, że niektóre osoby niewidome są całkowicie zależne od jednej osoby, np. matki. Jednej odpowiedzi udzieliło 33 badanych natomiast dwóch 22 osoby i trzech 10 osób. Dlatego też wykonałam poniższe zestawienie (Wykres 6). Znacząco częściej jednej odpowiedzi udzielały osoby z niskim i średnim wynikiem KPIKS-20. Pozostałe wyniki są mniej więcej rozłożone równomiernie. 
Wykres 6. Liczba odpowiedzi w pytaniu dotyczącym osób pomagających badanym jako asystenci/przewodnicy z uwzględnieniem podziału na wysoki, średni i niski wynik KPIKS-20

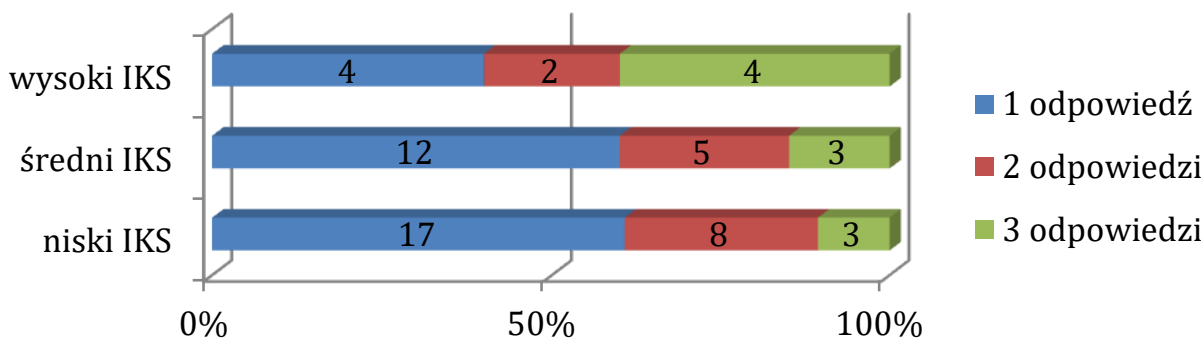

Źródło: Badania własne.

Podsumowując część dotyczącą kapitału społecznego, trudno wyciągnąć jednoznaczne wnioski z badań na tak niewielkiej grupie, jednak można zauważyć, że wyniki testu KPIKS-20 nie do końca pokrywają się z wynikami pytań ankietowych dotyczących elementów kapitału społecznego. Przyczyną takich rozbieżności niekoniecznie muszą być możliwe błędy w obu narzędziach badawczych. Rzeczywistość społeczna jest na tyle skomplikowana, że jej badanie jest bardzo trudne. Ponadto osoby z niepełnosprawnością wzroku zgłaszały wątpliwości do pytań w teście KPIKS-20. Trudno było niektórym osobom wytłumaczyć, że pytania mają charakter hipotetyczny i np. w pytaniu „Czy znasz kogoś, kto mógłby się zająć Twoimi dziećmi” osoby zastanawiały się, co zaznaczyć, jeżeli nie mają dzieci. Podobnie było z pytaniem „Czy znasz kogoś, kto mógłby dać Ci wsparcie psychiczne, gdyby opuścił Cię partner/partnerka”, ponieważ osoby, które nie mają partnera, skupiały się na tym fakcie, a nie na tym, czy znają osobę, która w takiej hipotetycznej sytuacji by ich wsparła. Z kilkoma innymi pytaniami były często podobne problemy, dlatego mogę przypuszczać, że część odpowiedzi przez niektóre osoby była zaznaczona „na chybił trafił".

Na podstawie niektórych pytań i widocznej zależności pomiędzy ich wynikiem a danymi z testu KPIKS-20 można przyjąć, że wyniki są 
Joanna Kapias - Kapitał społeczny osób niewidomych...

mimo wszystko bliskie rzeczywistości, skutkiem czego mogą być użyte przy analizie dotyczącej rehabilitacji zawodowej, którą opiszę w kolejnym podrozdziale mojej pracy.

\subsection{Sytuacja zawodowa badanej grupy}

W badaniu wzięło udział 48 osób aktywnych zawodowo, 11 poszukujących pracy, 7 niepracujących i nieposzukujących, 7 uczących się i 2 uczęszczające na zajęcia w Warsztacie Terapii Zajęciowej (WTZ). Suma odpowiedzi wynosi 75 pomimo faktu, iż w badaniu wzięło udział 67 osób, ponieważ niektórzy respondenci udzielili dwóch odpowiedzi, np. równocześnie pracują i się uczą lub pracują, ale poszukują innego zajęcia. W grupie kobiet 23 respondentki były aktywne zawodowo, 7 poszukiwało pracy, 3 nie szukały zatrudnienia natomiast 4 uczyły się i dwie uczęszczały na zajęcia w WTZ. W grupie mężczyzn aktywnych zawodowo było 25 osób, 4 poszukujące, 4 nieposzukujące oraz 3 uczące się. Grupa ta nie może być grupą reprezentatywną nie tylko ze względu na zbyt małą liczebność, ale również na nieodpowiednie proporcje ze względu na aktywność zawodową Przypomnę, że zaledwie 18\% osób niewidomych i słabowidzących będących członkami PZN jest aktywnych zawodowo, podczas gdy osoby pracujące stanowią znaczącą większość osób badanych. Przyczyny takiego stanu rzeczy doszukuję się w fakcie, że do osób niewidomych, które nie pracują (zapewne też nie obsługują komputera, nie udzielają się społecznie), jest trudniej dotrzeć.

Większość osób badanych deklarowała, że pracuje. Łącznie było to 50 odpowiedzi. Grupę stanowiło 25 kobiet i 25 mężczyzn. W grupie tej 25 osób było w wieku produkcyjnym mobilnym, a 25 osób w wieku produkcyjnym niemobilnym. Ze względu na miejsce zamieszkania 24 osoby zamieszkują duże miasto, 8 średnie, 7 małe i 11 osób mieszka na wsi. Dzięki nowym technologiom miejsce zamieszkania osoby ze znaczną niepełnosprawnością wzroku nie dyskwalifikuje jej jako pracownika. Taka osoba może wykonywać pracę zdalnie, nie wychodząc z domu, jednak niezbędna jest umiejętność obsługi komputera przy- 
najmniej w podstawowym zakresie. Chcąc przedstawić strukturę zatrudnienia badanej grupy, nadmienię, iż prawie połowa badanych zatrudniona jest na otwartym rynku pracy (27 osób). Sporą część stanowią również osoby zatrudnione w zakładach pracy chronionej (12 osób), natomiast pozostali badani pracują dorywczo (7 osób), prowadzą własną działalność gospodarczą ( 4 osoby), w Warsztacie Terapii Zajęciowej (2 osoby) i w Zakładzie Aktywności Zawodowej (1 osoba). Suma odpowiedzi wynosi 53, ponieważ niektórzy pracują równocześnie w dwóch miejscach, np. w zakładzie pracy chronionej i dorywczo.

Chcąc opisać sytuację zawodową grupy badanych, poza obiektywnymi faktami, jak miejsce zatrudnienia czy zgodność z wykształceniem, warto wziąć pod uwagę również subiektywną ocenę sytuacji respondentów. W ankiecie opcję „jestem bardzo zadowolony z mojej obecnej sytuacji zawodowej” wybrało 15 osób. Odpowiedź „nie jest źle, ale mogłoby być lepiej" zaznaczyły 22 osoby, a 10 osób stwierdziło, że jest „umiarkowanie zadowolona”. Niezadowolenie zadeklarowała tylko jedna osoba, która w dalszej części ankiety ujawniła, że intensywnie poszukuje innego miejsca pracy.

Bardzo interesującym wg mnie rezultatem badań jest zestawienie danych na temat tego, skąd badani dowiedzieli się o ofercie pracy, z której skorzystali (w jaki sposób znaleźli pracę). Okazuje się, że w potocznych opiniach przeceniamy rolę Internetu. Spośród 50 aktywnych zawodowo osób ze znaczną niepełnosprawnością wzroku zaledwie 4 znalazły pracę za pośrednictwem Internetu. Ku mojemu zaskoczeniu ani jedna osoba nie pozyskała informacji o wolnym stanowisku pracy z mediów (prasa, radio, telewizja), a zaledwie 3 z pomocą Powiatowego Urzędu Pracy (PUP). Okazuje się, że najbardziej skuteczne są kontakty osobiste, bo aż 22 osoby o ofercie pracy dowiedziały się od znajomych/rodziny, a 12 osobom pracodawca sam zaproponował pracę. Pozostałe 7 osób wybrało odpowiedź „inne”, w której wyjaśniali okoliczności zdobycia zatrudnienia, takie jak np.:

- „Roznosiłem CV do różnych firm i pracodawca odpowiedział.” (4 podobne odp.), 
Joanna Kapias - Kapitał społeczny osób niewidomych...

- „Sam znalazłem pracodawcę i zaproponowałem zakres obowiązków. A on się zgodził.",

- „Organizacja pozarządowa”,

- „Pracodawcę znalazłem poprzez projekt zatrudnienia wspomaganego, w którym korzystałem z pomocy trenera pracy."

Pytanie zostało pominięte przez osoby prowadzące własną działalność gospodarczą, a także uczestników WTZ i ZAZ.

Na podstawie powyższych wyników można uszeregować sposoby szukania pracy od najskuteczniejszego po najmniej skuteczny.

Tabela 3. Ranking sposobów szukania pracy wg skuteczności mierzonej w liczbie osób badanych, które poprzez dany sposób znalazły zatrudnienie

\begin{tabular}{|l|c|}
\hline \multicolumn{1}{|c|}{ Metoda poszukiwania pracy } & $\begin{array}{c}\text { Liczba badanych, } \\
\text { które znalazły pracę } \\
\text { w ten sposób }\end{array}$ \\
\hline Poszukiwanie informacji wśród znajomych i rodziny & 22 \\
\hline $\begin{array}{l}\text { Umożliwienie pracodawcy „zauważenia siebie” poprzez } \\
\text { różnego rodzaju działania tak, by on sam złożył ofertę. }\end{array}$ & 12 \\
\hline Roznoszenie CV do potencjalnych miejsc pracy & 5 \\
\hline Szukanie ofert w Internecie & 4 \\
\hline Korzystanie z usług PUP & 3 \\
\hline Szukanie ofert w mediach (prasa, radio, telewizja) & 0 \\
\hline
\end{tabular}

Źródło: Opracowanie własne na podstawie badań własnych

W mojej opinii najlepiej jest łączyć wszystkie możliwe sposoby, zwiększając w ten sposób prawdopodobieństwo znalezienia zatrudnienia. Jest to istotne tym bardziej, że osoby ze znacznym stopniem dysfunkcji wzroku są mniej chętnie zatrudniane niż osoby pełnosprawne.

W zestawieniu z ogólną liczbą respondentów (67) liczba osób niepracujących stanowi znaczną mniejszość (17 osób), jednak szczegółowa analiza sytuacji zawodowej tej małej grupki jest w mojej opinii 
ważna. Na grupę tę składa się 10 kobiet i 7 mężczyzn. Osoby te zamieszkują duże miasta ( 5 osób), średnie miasta (4 osoby), małe miasta (2 osoby) i wieś (5 osób); 12 osób jest w wieku produkcyjnym mobilnym, natomiast $6 \mathrm{w}$ wieku produkcyjnym niemobilnym. Warto nadmienić, że 3 osoby z tej grupy studiują i równocześnie poszukują pracy, nie są więc jeszcze typowymi bezrobotnymi. Ważną informacją jest również to, że 6 osób z różnych względów w ogóle nie poszukuje pracy. W analizowanej grupie 6 osób jest bezrobotnych przez całe życie, kolejne 3 osoby nie pracują od 10 lat, a pozostałe są na stażach bezrobocia wynoszących 6 lat, 3 lata, 21 miesięcy, 5 miesięcy, 4 miesiące i 0 u osób studiujących.

Osoby, które szukają pracy, zostały poproszone o zaznaczenie, z jakich sposobów korzystają. Najczęściej pojawiającą się odpowiedzią był Internet (8), następnie szukanie informacji wśród rodziny/znajomych (4), roznoszenie CV (1), inne (1 - udział w projekcie), media (1), nikt nie zaznaczył PUP. Jak stwierdziłam w poprzednim rozdziale, szukanie pracy przez Internet nie jest aż tak skuteczne, jak mogłoby się wydawać, jednak czasami można natrafić na interesującą ofertę. Jak już wspomniałam, warto zwiększać szansę na znalezienie pracy poprzez wykorzystywanie wszystkich możliwych sposobów szukania ofert. Okazuje się jednak, że z dwóch metod jednocześnie korzystają tylko 3 osoby, a z trzech metod tylko jedna osoba. Nasuwa się więc pytanie, czy pozostałe osoby szukają pracy w sposób zaangażowany, czy tylko stwarzają takie pozory. Tego problemu nie jestem w stanie rozstrzygnąc na podstawie zebranych danych. W mojej opinii wskazane byłyby w tym zakresie szczegółowe badania osób ze znaczną niepełnosprawnością wzroku poszukujących pracy.

\subsection{Kapitał społeczny a sytuacja zawodowa badanej grupy}

W poprzednich częściach opracowania scharakteryzowałam grupę badanych, określiłam, jaki jest ich indywidualny kapitał społeczny zarówno za pomocą testu KPIKS020, jak i badań ankietowych, a także scharakteryzowałam pokrótce ich obecną sytuację zawodową. W ni- 
Joanna Kapias - Kapitał społeczny osób niewidomych...

niejszej, najważniejszej dla moich badań części, postaram się zestawić dane dotyczące kapitału społecznego i sytuacji zawodowej badanych celem ustalenia zależności pomiędzy nimi.

W pierwszej kolejności zestawię wyniki KPIKS-20 z faktem, czy dana osoba pracuje. Bardziej szczegółowo (uwzględniając poszukiwanie lub nie pracy) skupię się na tym, opisując tylko osoby niepracujące.

Wykres 7. Wynik KPIKS-20 z uwzględnieniem wszystkich stenów a sytuacja zawodowa respondentów

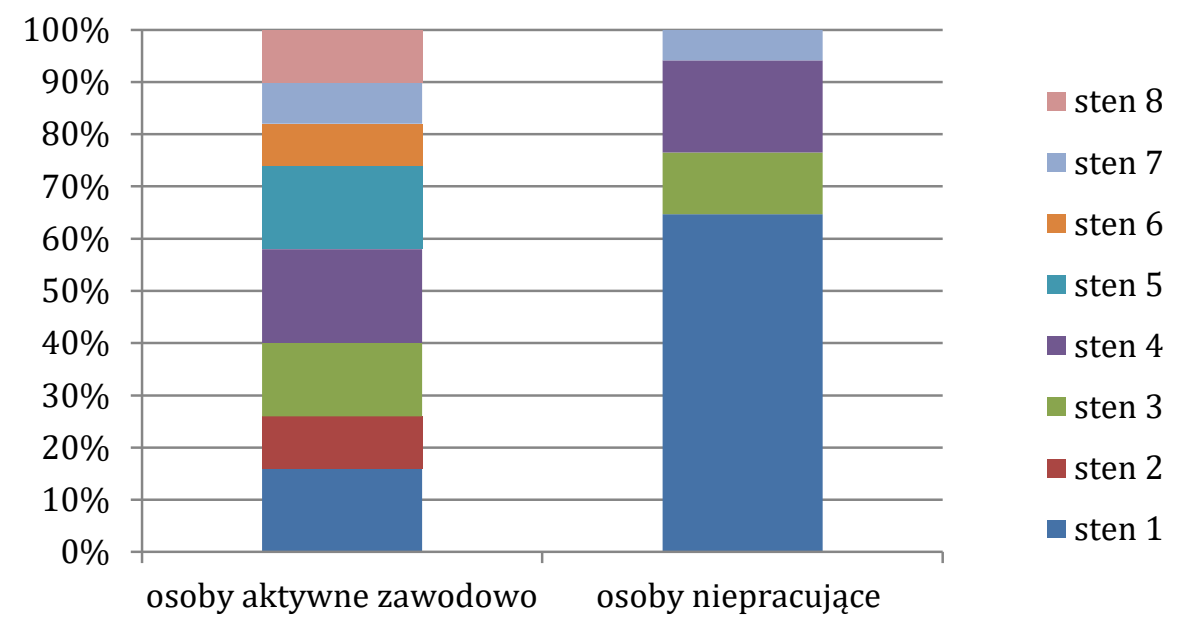

Źródło: Badania własne.

Uwzględniając podział na wszystkie steny, nietrudno zauważyć, że wśród osób aktywnych zawodowo steny są bardziej rozłożone pomiędzy wszystkie możliwości, natomiast wśród osób niepracujących większość jest przyporządkowana do poziomu 1, czyli do najniższego z możliwych wyniku IKS, steny 8,6 i 5 nie pojawiają się w ogóle, a 7 tylko raz. Znaczące różnice w poziomie kapitału społecznego będą widoczne, jeżeli powyższe dane przedstawimy za pomocą podziału na 3 poziomy IKS, gdzie steny 1,2 i 3 to niski poziom kapitału. 
Wykres 8. Wynik KPIKS-20 z podziałem na niski, średni i wysoki poziom IKS a sytuacja zawodowa respondentów

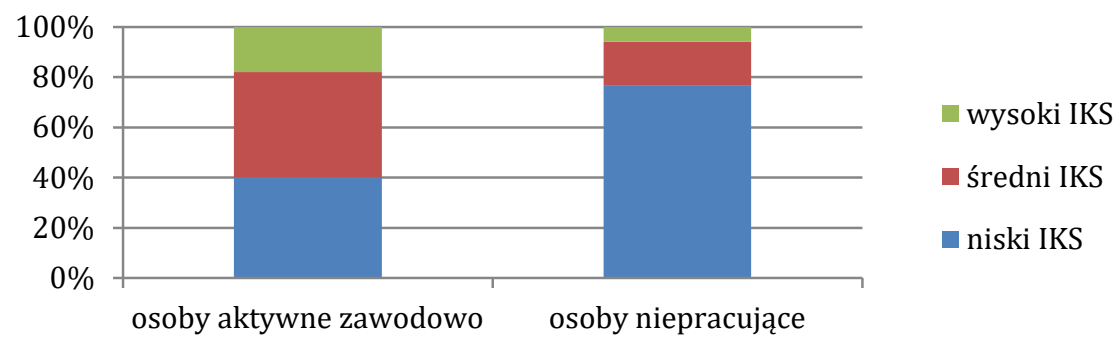

Źródło: Badania własne.

Dzięki takiemu przedstawieniu danych można bez wątpienia stwierdzić, że osoby niepracujące częściej niż pracujące posiadają niski poziom indywidualnego kapitału społecznego. Warto też nadmienić, że jedyna osoba niepracująca, która posiada wysoki IKS, jest poszukującym pracy studentem, natomiast 2 z 3 osób ze średnim wynikiem to student i osoba, która nie chce pracy znaleźć. Powyższe wyniki z dużą dozą prawdopodobieństwa potwierdzają moją hipotezę, jakoby osoby z niższym poziomem indywidualnego kapitału społecznego były bardziej narażone na stan bezrobocia. Podobne zależności pojawiły się po zestawieniu wszystkich pytań ankiety dotyczących kapitału społecznego z faktem posiadania zatrudnienia lub jego brakiem. Ze względu na ogrom materiału zmuszona jestem pominąć ten element. Podsumowując jednak ten wycinek moich badań, który przytoczyłam, można stwierdzić, iż zachodzi związek pomiędzy poziomem kapitału społecznego mierzonego za pomocą testu KPIKS-20, a także elementami kapitału społecznego badanymi z wykorzystaniem ankiety a statusem zawodowym badanych osób niewidomych. Osoby posiadające wyższy kapitał społeczny lepiej radzą sobie na rynku pracy. 
Joanna Kapias - Kapitał społeczny osób niewidomych...

\section{Wnioski}

Na podstawie powyższej analizy można wysnuć następujące odpowiedzi na postawione pytania badawcze.

\subsection{Jaki jest indywidualny kapitał społeczny osób niewidomych w wieku produkcyjnym?}

Znacząca większość wszystkich badanych niewidomych przyznała, że zgadza się ze stwierdzeniem „w życiu pomaga to, kogo się zna”, choć ich sieć kontaktów i ogólny poziom kapitału społecznego jest bardzo zróżnicowany. Zebrane dane wskazują, że poziom kapitału społecznego nie jest determinowany przez takie czynniki, jak płeć, miejsce zamieszkania, fakt członkostwa w jakiejś organizacji pozarządowej lub zrzeszeniu czy liczba osób wspólnie gospodarujących. Zauważyć można jednak inne zależności. Badania wykazały, że osoby w wieku produkcyjnym niemobilnym (po 45 roku życia) częściej posiadają wysoki kapitał społeczny niż osoby młodsze. Wśród osób z wykształceniem podstawowym i zawodowym dominował niski wynik testu KPIKS-20, natomiast w pozostałych grupach wyniki były zróżnicowane. Warto zauważyć, że również wśród osób z wyższym wykształceniem pojawiały się obok wysokich i średnich również niskie wyniki KPIKS-20. Osoby z niskim i średnim IKS częściej wykazywały tendencje do przekonania, że „większości ludzi nie można ufać”. Sam wynik KPIKS-20 nie pokrywał się idealnie z odpowiedziami uzupełniającymi w części ankietowej i zazwyczaj w każdej grupie pojawiały się zróżnicowane deklaracje. Nie zmienia to jednak faktu, że pewne tendencje są widoczne. Osoby z niskim IKS częściej niż pozostałe zgadzały się ze stwierdzeniem, że „każdy myśli tylko o sobie”, choć i tak było tych odpowiedzi niewiele. Tylko osoby z niskim poziomem IKS deklarowały, że nie mają nikogo, na kogo zawsze mogłyby liczyć lub nie miały zdania w tej kwestii. Wśród osób z niskim poziomem IKS również częściej pojawiały się opinie, że „świat jest z natury zły”, częściej nie wierzyły, że poradzą sobie w każdej sytuacji. Osoby z niskim poziomem IKS częściej nie ukończyły żadnego kursu ani szko- 
lenia, a ocena ich umiejętności niezależnie od wszystkiego zazwyczaj była wysoka lub bardzo wysoka. Jak wspominałam już w podsumowaniu jednego z podrozdziałów, odpowiedzi niektórych respondentów w części testowej (KPIKS-20) mogły być miejscami przekłamane ze względu na niezrozumienie poleceń, pomimo tego zależności pomiędzy niektórymi pytaniami uzupełniającymi są widoczne. Warto również mieć na uwadze, że badana grupa osób może zawyżać wyniki, gdyż zapewne trudniej jest dotrzeć do osób zamkniętych w domach, nieudzielających się w PZN, niekorzystających z Internetu itp. Pomimo faktu, iż grupa, do której dotarłam, może zawyżać ogólne wyniki, niski poziom kapitału społecznego $\mathrm{w}$ tej grupie występuje częściej niż wśród osób pełnosprawnych.

\subsection{Jaka jest sytuacja zawodowa osób niewidomych w wieku produkcyjnym?}

Opisane w części teoretycznej statystyki dotyczące zatrudnienia osób niewidomych są mniej optymistyczne niż niniejsze wyniki badań. Związane to może być ze zbyt małą grupą badawczą oraz specyfiką grupy osób, do których udało mi się dotrzeć. W badanej grupie sytuację zawodową można ocenić jako dobrą, ponieważ większość badanych pracuje i jest raczej zadowolona z obecnej sytuacji. Wśród osób niepracujących częściej były kobiety, ale nie była to istotna różnica. Wśród osób pracujących znaczną liczbę stanowiły osoby pracujące na otwartym rynku, a następnie osoby zatrudnione w zakładach pracy chronionej. Warte uwagi jest w mojej opinii to, w jaki sposób osoby znalazły zatrudnienie. Najczęściej pojawiającą się odpowiedzią było uzyskanie informacji o stanowisku pracy od znajomych lub rodziny. Przeceniany natomiast jest Internet i Urząd Pracy. Grupa osób nieaktywnych zawodowo była na tyle mała (17), że ciężko wysnuwać jakieś szersze wnioski. Najistotniejszym wnioskiem jest w mojej opinii fakt, że część osób deklarująca się jako poszukujące pracy (11) zazwyczaj korzysta tylko z jednego sposobu szukania ofert (najczęściej Internet). Nasuwa to wspomniane wcześniej pytanie, czy osoby 
Joanna Kapias - Kapitał społeczny osób niewidomych...

te nie potrafią szukać pracy, czy może nie są w poszukiwania na tyle zaangażowane, jakby były, gdyby bardzo im zależało na znalezieniu zatrudnienia.

\subsection{Jaki jest zwiq̨zek pomiędzy Kapitałem Społecznym a sytuacją zawodową dorosłych osób niewidomych w wieku produkcyjnym?}

$\mathrm{Na}$ podstawie zebranych danych można zauważyć związek pomiędzy kapitałem społecznym badanych osób. Wyniki KPIKS-20 były bardzo zróżnicowane, jednakże osoby niepracujące dużo częściej posiadały niski wynik, niż osoby aktywne zawodowo. Osoby pracujące częściej zgadzały się ze stwierdzeniem, że „większości ludzi można ufać”. Osoby nieaktywne zawodowo częściej zgadzały się ze stwierdzeniem „każdy myśli tylko o sobie”, częściej deklarowały, że nie mają kogoś, na kogo mogłyby zawsze liczyć. Osoby niepracujące również częściej zgadzały się z opinią, że „świat jest z natury zły” i rzadziej wierzyły, że w każdej sytuacji sobie poradzą.

\section{Podsumowanie}

Aktywizacja zawodowa osób ze znaczną niepełnosprawnością wzroku to zagadnienie wieloaspektowe związane $\mathrm{z}$ rehabilitacją, edukacją, wychowaniem, zatrudnianiem osób niepełnosprawnych oraz pomocą społeczną. Elementy te są również związane z budowaniem indywidualnego kapitału społecznego tychże osób. Kapitał społeczny, jaki posiada osoba niewidoma, często ma znaczenie dla jej sytuacji zawodowej. Dlatego należy dbać o to, by uczyć osoby z niepełnosprawnością wzroku, w jaki sposób mogą go budować.

\section{Bibliografia:}

Bogacz-Wojtanowska E., Partycypacja społeczna (w tym polityczna) osób niepełnosprawnych UE/EOG oraz sytuacja w Polsce. Przesłanki prawne i społeczne upodmiotowienia środowisk osób niepełnosprawnych, http://polscy 
niepelnosprawni.agh.edu.pl/wp-content/uploads/1_3_06_2_raport_eksper cki_analiza_porownawcza_UE_PL_modul_I_Bogacz_Wojtanowska.

Bokajło W., Amerykańskie korzenie kapitału społecznego, [w:] M. Klimowicz, W. Bokajło (red.) Kapitał społeczny - interpretacje, impresje, operacjonalizacja, Wyd. Fachowe CeDeWu.pl, Warszawa 2010 [dostęp:19-11-2016].

Brzezińska A. I., Kaczan R., Piotrowski K., Rycielski P., Uwarunkowania aktywności zawodowej osób z ograniczeniami sprawności: kapitał osobisty i społeczny, „Nauka” 2009, nr 2.

Działek J., Kapitał społeczny, jako czynnik rozwoju gospodarczego w skali regionalnej i lokalnej w Polsce, Wyd. Uniwersytetu Jagiellońskiego, Kraków 2011.

Fajfer-Kruczek I., Wykluczenie społeczne osób z niepełnosprawnościq w środowisku lokalnym, Wyd. Uniwersytetu Śląskiego, Katowice 2015.

Informacja Rządu Rzeczypospolitej Polskiej o działaniach podejmowanych w 2009 roku na rzecz realizacji postanowień uchwały Sejmu Rzeczypospolitej Polskiej z dnia 1 sierpnia 1997 „Karta praw osób niepełnosprawnych", Warszawa 2010.

Kapias J., Kapitał społeczny osób niewidomych $w$ wieku produkcyjnym a ich sytuacja na rynku pracy, niepublikowana praca magisterska (promotor: prof. dr hab. Zenon Gajdzica), Cieszyn 2017.

Konarska J., Formy wsparcia rehabilitacji osób z niepełnosprawnościq wzroko$w q$ [w:] B. Grochmal-Bach, M. Alberska, A. Grzebionga (red.), Wspomaganie funkcjonowania psychospołecznego osób z niepełnosprawnościq, Wyd. WAM, Kraków 2013.

Zaufanie społeczne, BS/33/2012, Centrum Badania Opinii Społecznej, Warszawa 2012.

Łukasiak E., Oleksiak E., Osoby niewidome i niedowidzq̨ce, [w:] Zbiorczy raport z diagnozy świadczonych usług z zakresu rehabilitacji społecznej dla osób niepełnosprawnych $w$ Polsce, Warszawa 2011; http://www.koalicjaon.org.pl /photo/File/projekt_standardy/raport_zbiorczy_z_diagnozy_swiadczonych _uslug_rehabilitacyjnych.pdf [dostęp: 05-11-2016].

Majewski T., Poradnik metodyczny dla nauczycieli pracujących z dziećmi $z$ uszkodzonym wzrokiem $w$ systemie integracyjnym, Przedsiębiorstwo Wydawnicze Związku Niewidomych „Print 6”, Lublin 1997.

Majewski T., Psychologia niewidomych i niedowidzacych, Wyd. PWN, Warszawa 1985.

Mikiewicz P., Kapitał społeczny i edukacja, Wyd. PWN, Warszawa 2014. 
Joanna Kapias - Kapitał społeczny osób niewidomych...

Niemierko B., Jak mierzyć kapitał ludzki i kapitał społeczny? Edukacyjne perspektywy operacjonalizacji pojęć ekonomicznych, „Zeszyty Naukowe Akademii Marynarki Wojennej", 2011, nr 4.

Ossowski R., Pedagogika niewidomych i niedowidzacych, [w:] W. Dykcik (red.) Pedagogika Specjalna, Wyd. Naukowe UAM, Poznań 1997.

Badania wpływu kierunku i poziomu wykształcenia na aktywność zawodowq osób niepełnosprawnych - Raport końcowy, www.pfron.org.pl/ftp/dokumen ty/Badania_i_analizy/Raport_CZESC_1z6_final.pdf [dostęp: 19-11-2016].

Pilch T., Bauman T., Zasady badań pedagogicznych. Strategie ilościowe i jakościowe, Wyd. Akademickie „Żak,” Warszawa 2001.

Przybyś J., Sauś J., Kapitał społeczny. Szkice socjologiczno-ekonomiczne, Wyd. Politechniki Poznańskiej, Poznań 2004.

Radoła M., Kapitał społeczny, a osiagnięcia szkolne ucznia, „Studia Edukacyjne" 2013, nr 27.

Rozporządzenie Ministra Gospodarki, Pracy i Polityki Społecznej z dnia 15 lipca 2003 (z późn. zm.), w sprawie orzekania o niepełnosprawności i stopniu niepełnosprawności, Załącznik do obwieszczenia Ministra Pracy i Polityki Społecznej z dnia 8 lipca 2015 r. (poz. 1110).

Rymsza A., Klasyczne koncepcje kapitału społecznego, [w:] T. Kaźmierczak, M. Rymsza (red.) Kapitał Społeczny. Ekonomia społeczna, Wyd. Instytut Spraw Publicznych, Warszawa 2007.

Skawińska E., Kapitał społeczny w rozwoju regionu, Wyd. PWN, Warszawa 2012.

Styła R., Kwestionariusz do Pomiaru Indywidualnego Kapitału Społecznego (KPIKS) - wstępna propozycja oparta na idei generatora zasobów Toma Snijdersa, „Psychologia Społeczna” 2009, t. 4.

Trutkowski C., Mandes S., Kapitał Społeczny w małych miastach, Wyd. Naukowe Scholar, Warszawa 2005.

Wróbel P., Rola i znaczenie kapitału społecznego w spółdzielniach socjalnych analiza empiryczna wymiarów kapitału, www.delibra.bg.polsl.pl/Content/ 27299/BCPS_31023_-_Rola-i-znaczenie-kap_0000.pdf [dostęp: 19-11-201 6]. 